\title{
EVALUATION OF IMPORTANT FACTORS FOR PHYSICAL EXERCISE TO MAINTAIN HEALTH
}

\author{
AVALIAÇÃO DE FATORES IMPORTANTES PARA O EXERCÍCIO FISICO PARA MANTER A SAÚDE \\ EVALUACIÓN DE FACTORES IMPORTANTES DEL EJERCICIO FÍSICO PARA MANTENER LA SALUD
}

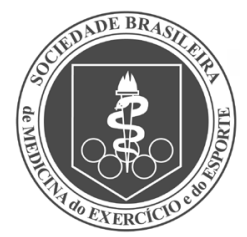

Original Article

ARTIGO ORIGINAL

Artículo Original

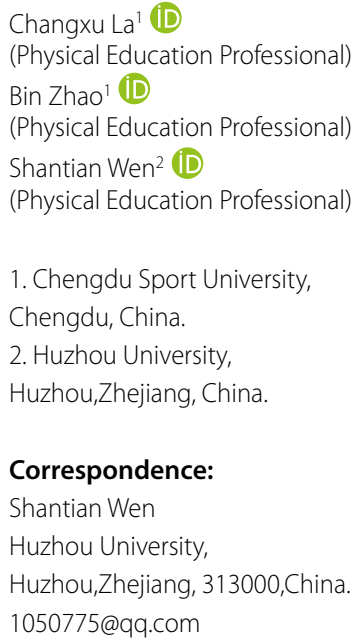

\section{Correspondence:}

Shantian Wen

Huzhou University,

Huzhou,Zhejiang, 313000,China. 1050775@qq.com

\begin{abstract}
Introduction: In recent years, people's physical fitness continues to show a slow decline, so the maintenance of human health is very important. Object: The thesis researches the effect of student group sports and analyzes the influencing factors of student group sports. Method: The thesis uses mathematical statistics to study student groups'sports activities and influencing factors. Results: The student group is not satisfied with the extracurricular sports activities carried out by the school. The community has little influence on the sports behavior of the student group. Conclusion: This study provides a realistic and theoretical basis for the student group to implement the school sports documents, rules and regulations, and opinions and promote the student group's physical and mental health. Level of evidence Il; Therapeutic studies - investigation of treatment results.
\end{abstract}

Keywords: Student; Sports; Attention to Effects; Influencing Factors; Exercise.

\section{RESUMO}

Introdução: Nos últimos anos, a aptidão física das pessoas continua apresentando um lento declínio, por isso a manutenção da saúde humana é muito importante. Objetivo: a tese pesquisa o efeito dos esportes coletivos de alunos e analisa os fatores que os influenciam. Método: a tese usa estatística matemática para estudar as atividades esportivas e os fatores de influência dos grupos de alunos. Resultados: O grupo de alunos não está satisfeito com as atividades esportivas extracurriculares realizadas pela escola. A comunidade tem pouca influência no comportamento esportivo do grupo de alunos. Conclusão: Este estudo fornece uma base teórica e realista para o grupo de alunos implementar os documentos, regras e regulamentos do esporte escolar, e opiniões e promover a saúde física e mental do grupo de alunos. Nível de evidência ll; Estudos terapêuticos investigação dos resultados do tratamento.

Descritores: Grupos de Alunos; Esportes; Atenção aos Efeitos; Fatores de Influência; Exercício Físico.

\section{RESUMEN}

Introducción: En los últimos años, la condición física de las personas continúa mostrando un lento declive, por lo que el mantenimiento de la salud humana es muy importante. Objeto: La tesis investiga el efecto de los deportes de grupo de estudiantes y analiza los factores que influyen en los deportes de grupo de estudiantes. Método: La tesis utiliza estadística matemática para estudiar las actividades deportivas de los grupos de estudiantes y los factores de influencia. Resultados: El grupo de estudiantes no está satisfecho con las actividades deportivas extraescolares que realiza la escuela. La comunidad tiene poca influencia en el comportamiento deportivo del grupo de estudiantes. Conclusión: Este estudio proporciona una base realista y teórica para que el grupo de estudiantes implemente los documentos, reglas y regulaciones y opiniones de deportes escolares y promueva la salud física y mental del grupo de estudiantes. Nivel de evidencia Il; Estudios terapéuticos: investigación de los resultados del tratamiento.

Descriptores: Grupos de Estudiantes; Deportes; Atención a los Efectos; Factores de Influencia; Ejercicio Físico.

\section{INTRODUCTION}

Young people are the future of the country and the hope of the nation. Their physical health is directly related to the future development of China and the prosperity and decline of the nation. The results show that compared with the health level before 2010, the obesity detection rate continues to increase; the national physical fitness continues to show a slow decline; the health compliance rate of people at all stages is still high, and the detection rate of many people has a significant increase in poor health. The survey results Very worrying. Why does the survey result deviate from the attention and emphasis on human sports life in peacetime? Therefore, it is particularly necessary for us to investigate and analyze the implementation and implementation effects of sports documents, rules and regulations and opinions related to the human body, to find out the existing problems, and to propose improved countermeasures against the problems. Here is a study on the effect of physical exercise-related sports. The paper analyzes the influencing factors of physical exercise-related sports in order to find the existing problems and propose corresponding countermeasures to provide practical and theoretical basis for the implementation of healthy sports documents, rules and regulations and opinions for human health. Effectively promote the development of physical and mental health.' 
METHOD

\section{Object}

This paper randomly selects ten cities, and randomly selects 120 people from each city as the research object. Through literature method, questionnaire survey method, interview method and mathematical statistics method, the effect of carrying out physical exercise related sports is researched.

\section{STATISTICAL METHODS}

\section{Partial normal distribution}

In 1985, Azzalini first researched and proposed a partial normal distribution. If the random variable $Y$ obeys the partial normal distribution, that is, Y SN $\left(\mu, \sigma^{2}, \lambda\right)$, where $\mu$ represents the position parameter, $\sigma$ represents the scale parameter, and $\lambda$ represents the skewness parameter, then its probability density function can be expressed. ${ }^{2}$

$$
f(y)=\frac{2}{\sigma}\left(\frac{y-\mu}{\sigma}\right) \Phi\left(\lambda \frac{y-\mu}{\sigma}\right)
$$

Where $\varphi(\cdot), \Phi(\cdot)$ is the density function and distribution function of the standard normal distribution, respectively. When the skewness parameter $\lambda=0$, the formula (1) degenerates to the normal distribution density function, that is, the partial normal distribution degenerates to the normal distribution at this time. Figure 1 shows the image of the standard normal distribution. ${ }^{3}$ The mean and variance of the partial normal distribution are

$$
\operatorname{Mean}(Y)=E(Y)=\mu+\mu_{0}(\lambda) \sigma, \operatorname{Var}(Y)=\sigma_{0}^{2}(\lambda) \sigma^{2}
$$

Among them

$$
\mu_{0}(\lambda) \square \sqrt{\frac{2}{\pi}} \frac{\lambda}{\sqrt{1+\lambda^{2}}}, \sigma_{0}^{2}(\lambda) \square 1-\frac{2 \lambda^{2}}{\pi\left(1+\lambda^{2}\right)}
$$

\section{The partial standard mode regression model}

Mode is the most frequent sign value in the population. It describes most levels of the central tendency of the overall data. In skewed data analysis, the model is more widely used than the mean. ${ }^{4}$ According to Azzalini, the model under the partial normal distribution can be obtained. The expression is

$$
\operatorname{Mode}(Y)=\mu+m_{0}(\lambda) \sigma
$$

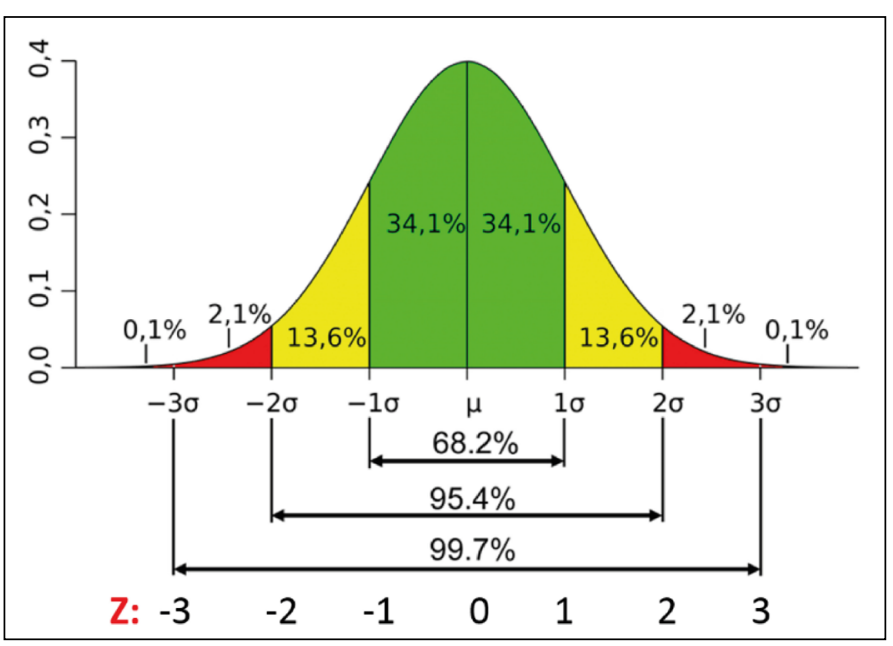

Figure 1. Image of standard normal distribution.
Among them

$m_{0}(\lambda) \approx \mu_{0}(\lambda)=\frac{t_{0}(\lambda) \sigma_{0}(\lambda)}{2}-\frac{\operatorname{sgn}(\lambda)}{2} \exp \left(-\frac{2 \pi}{|\lambda|}\right), t_{0}(\lambda) \square \frac{4-\pi}{2} \frac{\mu_{0}^{3}(\lambda)}{\sigma_{0}^{3}(\lambda)} \quad(5)$

This article establishes the mode regression model under partial standard data as:

$\left\{\begin{array}{l}y_{i} i \operatorname{ind} S N\left(\mu_{i}, \sigma^{2}, \lambda\right) \\ \sim \\ \operatorname{Mode}\left(y_{i}\right)=x_{i} \beta \\ \mu_{i}=x_{i} \beta-m_{0}(\lambda) \sigma \\ i=1, \cdots, n\end{array}\right.$

Where $Y_{i}$ is the explained variable, subject to a partial normal distribution with position parameter $\mu$, scale parameter $\sigma$, and skewness parameter $\lambda . x_{i}=\left(x_{i 1}, x_{i 2}, \cdots, x_{i p}\right)$ is an explanatory variable with $1 \times \mathrm{p}$ dimension, and $\beta=\left(\beta_{1}, \beta_{2}, \cdots, \beta_{p}\right)^{T}$ is a mode with dimension $\mathrm{p} \times 1$ unknown parameters of the regression model. ${ }^{5}$ Now given a set of observation data $\left(y_{i}, x_{i}\right), i=1, \cdots, n, y_{i}$ as random variables that independently obey a partial normal distribution, the linear regression model of equation (2) can be expressed as:

$$
y_{i}=f\left(x_{i}, \beta\right)+\varepsilon_{i}, i=1, \cdots, n,
$$

Where $f\left(x_{i}, \beta\right)=\mu_{i}+m_{0}(\lambda) \sigma=x_{i}, \beta$ is the linear function of the parameter $\beta$, and $\beta=\left(\beta_{1}, \beta_{2}, \cdots, \beta_{p}\right)^{T}$ is the coefficient vector of the regression equation. $\varepsilon=\left(\varepsilon_{1}, \varepsilon_{2}, \cdots, \varepsilon_{n}\right)^{T}$ is the random error and obeys $\varepsilon_{i} \square S N\left(-m_{0}(\lambda) \sigma, \sigma^{2}, \lambda\right), x_{i}=\left(1, x_{i 1}, \cdots, x_{i p}\right)$, Note that $X=\left(x_{1}, x_{2}, \cdots, x_{n}\right)^{T}$ is the design matrix of $\mathrm{n} \times \mathrm{p}$ dimension and rank $\mathrm{p}$, then the vector form of equation (3) is given

$$
y=f(X, \beta)+\varepsilon
$$

\section{RESULTS}

\section{Questionnaire survey}

When answering the questionnaire, the title is as follows: "Exercise for one hour a day, work healthy for 50 years, and live a happy life. Have you ever heard of it?", choose 1032 people who have heard of it, accounting for $90.4 \%$ of the total number; choose 110 people who have never heard of it, accounting for $9.6 \%$ of the total number. ${ }^{6}$

When answering the question "Is healthy people being squeezed by other cultural classes or other activities?", 1016 people who chose this phenomenon accounted for $89.0 \%$ of the total; 126 people who chose not this phenomenon accounted for the total $11.0 \%$ of the number of people.

In answering the question "Do you have an average of 1 hour of activities per day?", 318 people were selected, accounting for $27.8 \%$ of the total number; 824 people selected were not, accounting for $72.2 \%$ of the total number.

In answering the question "Do you often participate in your favorite sports?", 239 people who participated frequently were selected, accounting for $20.9 \%$ of the total number; 903 people who participated infrequently, accounting for $79.1 \%$ of the total number were selected.

When answering the question "How satisfied are you with outdoor sports activities?", 176 people were satisfied, accounting for $15.4 \%$ of the total; 423 people in general, accounting for $37.0 \%$ of the total were selected; 543 were unsatisfied People, accounting for $47.5 \%$ of the total number. 


\section{INVESTIGATION RESULTS AND ANALYSIS OF INFLUEN- CING FACTORS}

Investigation results and analysis of reasons why high school students do not participate in sports activities

When answering the questionnaire question "The main reason why you are unwilling to participate in sports activities (single choice)", the factors from high to low selection are, in order, the time required for learning and lack of exercise, and the impact of the sports environment (including sports coaches, friends, and sports regulations). System, compliance, etc.), family sports environmental impact (including family members and living environment, etc.), lack or lack of venues and facilities, no guidance or no one to participate in activities, not interested in sports, no special reasons, people's sports environmental impact, The result is shown in Figure 2.

From the data in the figure, it can be seen that the main reasons for reluctance to participate in sports activities are heavy learning and work, physical exercise environment, family environment, lack or absence of venues and equipment; people's environment has little impact on sports activities.

\section{Investigation results and analysis of reasons for high school students to participate in sports activities}

When answering the questionnaire question "What motivates you to do physical exercises (single choice)", the factors in descending order of the number of choices are the fun that physical activities bring to you, the improvement of physical fitness, and the impact of the physical environment (including teachers, classmates and Sports regulations, compliance, etc.), family sports environmental impact (including family members and living environment, etc.), media influence, sports celebrity influence, relatives and friends acquaintance influence, other reasons, people's sports environment influence, the results are shown in Figure 3.

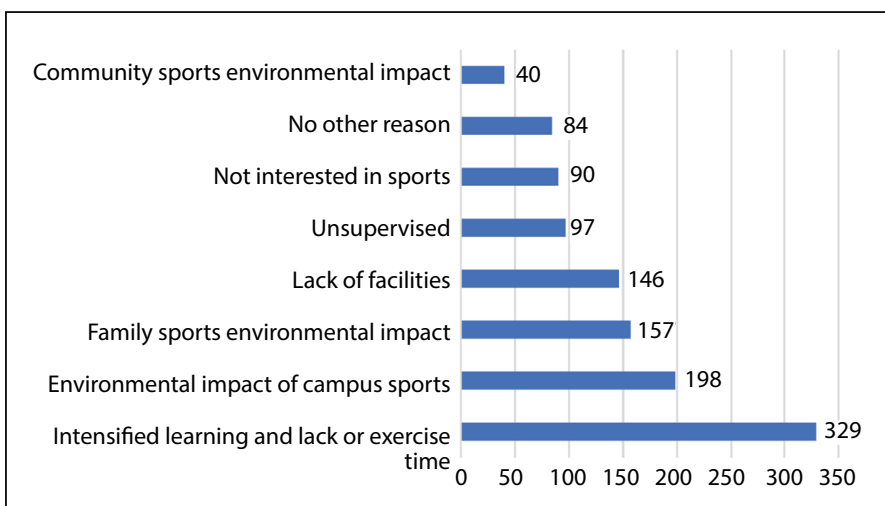

Figure 2. A list of reasons why people do not participate in sports activities.

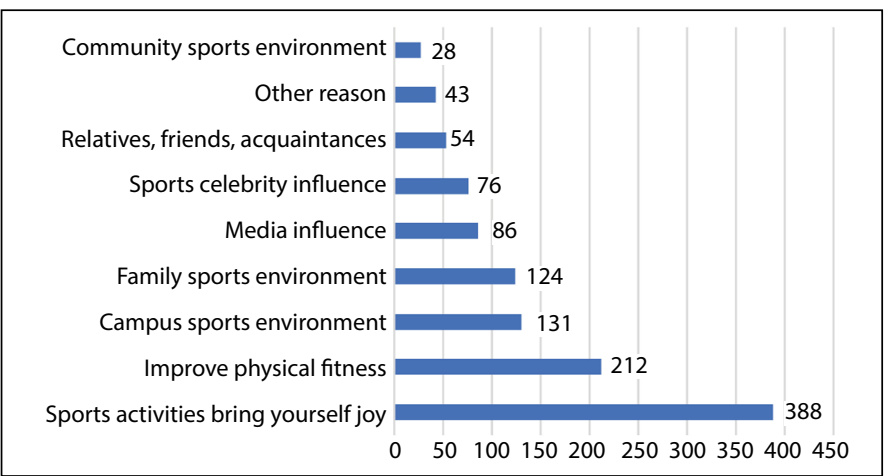

Figure 3. List of reasons to encourage people to participate in sports activities.
From the data in the figure, it can be seen that the main reasons for promoting physical exercise are the fun that physical activities bring to oneself, the improvement of physical fitness, the sports environment, and the family sports environment; among the reasons for promoting participation in sports activities ${ }^{8}$

\section{INVESTIGATION RESULTS AND ANALYSIS OF THE STA- TUS QUO OF THE INFLUENCE OF FAMILIES ON HIGH SCHOOL STUDENTS' SPORTS BEHAVIORS}

\section{influence of families on sports behaviors}

When answering the questionnaire question "Family factors that affect your participation in sports activities (multiple choices)", the factors that choose from high to low are people's attitude towards sports, people's habits of physical exercise, people's education level, and family sports consumption Status, other, and no family factors, the results are shown in Figure 4.

From the data in the figure, it can be seen that people's attitudes towards sports and people's physical exercise habits have a greater impact on sports behavior, which shows that people's support and encouragement of sports and people's role in leading by example have a positive impact on people's sports behavior.

Investigation results and analysis of the status quo of the impact of schools on high school students' sports behaviors

When answering the questionnaire question "Factors that affect your health in participating in sports activities (multiple choices)", the factors that choose from high to low are obesity pressure, healthy sports atmosphere, outdoor sports activities, venue equipment, and healthy The results of sports competitions, teaching, and others are shown in Figure 5.

This shows that the pressure of obesity restricts the body's enthusiasm for physical activities; healthy sports atmosphere and outdoor sports activities also fail to promote the body's physical activities.

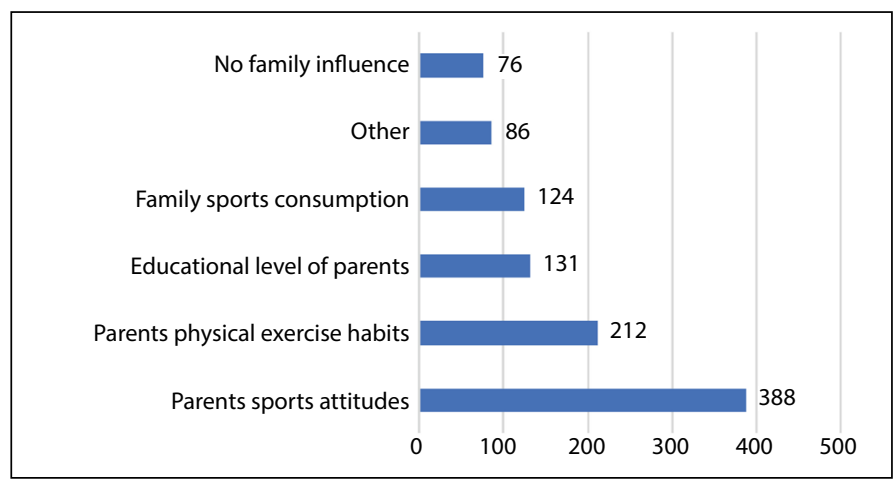

Figure 4. Summary of the influence of family on people's sports behavior.

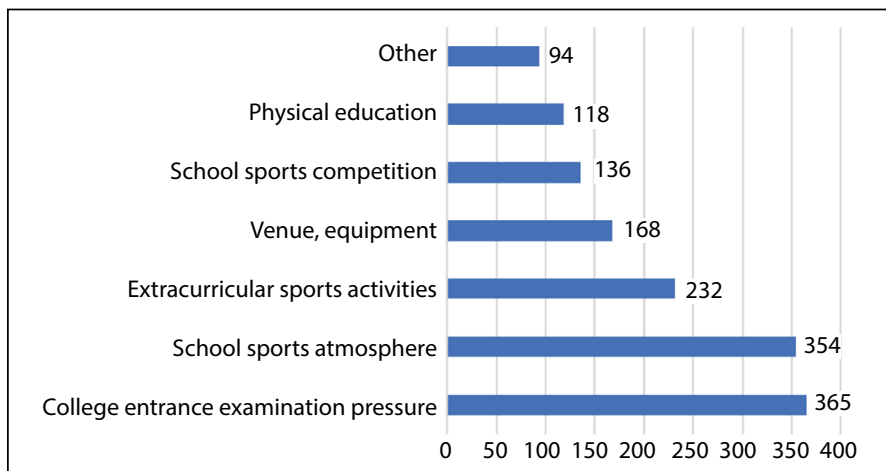

Figure 5. An overview of the impact of schools and other sports grounds on people's sports behaviors. 
Investigation results and analysis of the status quo of the impact of society (community) on high school students' sports behaviors

When answering the questionnaire question "Social (people) factors that affect your participation in sports activities (multiple choices)", the survey results are shown in Figure 6.

The most popular choice is no people's influence. The number of people is 356 , accounting for $31.2 \%$ of the total, which shows that human factors have little influence on sports behavior.

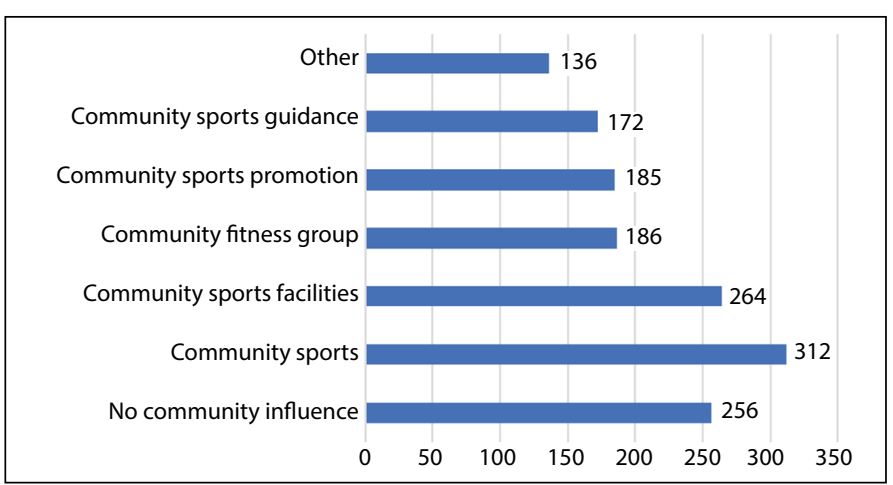

Figure 6. Overview of the impact of schools on people's sports behaviors.

\section{DISCUSSION}

\section{Cause analysis}

Through questionnaire surveys and interviews, it is learned that due to the influence of traditional concepts, physical health plays an important role in the family, health, and society. It is self-evident that sports life and sports activities are not guaranteed, and the body's physique is worrying.

From the individual level of the human body, whether to insist on physical exercise is the dominant need of the human body. Many people due to lazy thinking, determine the health and destiny of the human body to a certain extent. Other needs including physical activities are Less affected by the dominant need of thought. When sports activities conflict with lazy ideas, they often choose to be lazy instead of participating in physical exercises, reduce physical activities or give up physical activities. This is the physical exercise obtained from the investigation and analysis. The main reason for the poor development of related sports.

\section{Related countermeasures}

The country should consider the combination of sports and obesity systems, improve the obesity system, and still have a truly effective and relaxed living environment for sports. Two methods can be considered. One method is to conduct a national sports test, and the results of the sports test should be linked to many aspects, to enhance the enthusiasm of physical exercise and promote physical and mental health.

The state and educational administrative departments at all levels and health departments must implement and implement sports policies, rules and regulations, and document requirements, regard human physical and mental health as a major event related to the prosperity of the country and the prosperity and decline of the nation, and implement a full-time leadership responsibility system and The democratic supervision system puts the physical exercise of the human body in place and promotes the healthy growth of the human body.

Implement a democratic supervision system: The Ministry of Education, the State Sports General Administration and the Central Committee of the Communist Youth League jointly set up a national body sports supervision agency and formulate supervision rules. Supervising agencies should carry out their work independently, do not practice favoritism, conduct irregular visits and on-site investigations to different regions and different health, and can also conduct home visits or telephone interviews to understand the facts of people's implementation of sports policies and documents, and they are targeted. The improvement of the work to effectively promote the healthy development of people's body and mind.

\section{CONCLUSION}

Through questionnaire surveys and interviews, it is learned that due to the influence of traditional concepts, the status of healthy physical exercise in the family and society is self-evident. Worrying. People need to start from many aspects to strengthen physical exercise of the human body and improve physical fitness.

All authors declare no potential conflict of interest related to this article

AUTHORS' CONTRIBUTIONS: Each author made significant individual contributions to this manuscript. Changxu La: writing and performing surgeries; Bin Zhao: data analysis and performing surgeries; Shantian Wen: article review and intellectual concept of the article.

\section{REFERENCES}

1. Clevinger K, Petrie T, Martin S, Greenleaf C. The relationship of sport involvement and gender to physical fitness, self-efficacy, and self-concept in middle school students. Physical Educator. 2020;77(1): 154-72.

2. Burner A, Bopp M, Papalia Z, Weimer A, Bopp CM. Examining the relationship between high school physical education and fitness outcomes in college students. Physical Educator. 2019;76(1): 285-300.

3. Leuciuc, F. Effect of a one-semester conditioning activities on physical fitness of the students. Revista Românească pentru Educaţie Multidimensională. 2019;11(4): 136-46.

4. Ivanova NL, Korostelev AA. The impact of competitive approach on students' motivation in sport. Amazonia Investiga. 2019;8(18):483-90.
5. Pennington CG. Sport education and physical activity: Recommendations for maximizing the model. Int J Phys Educ Fit Sports. 2019;8(1): 122-5.

6. Simonton KL, Mercier K, Garn AC. Do fitness test performances predict students' attitudes and emotions toward physical education. Physical Education and Sport Pedagogy. 2019;24(6): 549-64.

7. Kuan G, Rizal H, Hajar MS, Chin MK, Mok MMC. Bright sports, physical activity investments that work: Implementing brain breaks in Malaysian primary schools. Br J Sports Med. 2019;53(14): 905-6.

8. Jaakkola T, Huhtiniemi M, Salin K, Seppälä S, Lahti J, Hakonen H, et al. Motor competence, perceived physical competence, physical fitness, and physical activity within Finnish children. Scand J Med Sci Sports. 2019;29(7):1013-21 